\title{
Replacement of Metaphylactic Antimicrobial Therapy by Oral Administration of Ligilactobacillus salivarius MP100 in a Pig Farm
}

\begin{abstract}
Odón J. Sobrino ${ }^{1}$, Claudio Alba ${ }^{2}$, Rebeca Arroyo ${ }^{2}$, Inés Pérez ${ }^{2}$, Lydia Sariego ${ }^{3}$, Susana Delgado ${ }^{3}$, Leónides Fernández ${ }^{4}$, Julián de María ${ }^{5}$, Pilar Fumanal ${ }^{5}$, Antonio Fumanal ${ }^{5}$ and Juan M. Rodríguez ${ }^{2 *}$

${ }^{1}$ Scientific Society of Veterinary Public and Community Health (SOCIVESC), Madrid, Spain, ${ }^{2}$ Department of Nutrition and Food Science, Complutense University of Madrid, Madrid, Spain, ${ }^{3}$ Department of Microbiology and Biochemistry, Dairy Research Institute of Asturias, Villaviciosa, Spain, ${ }^{4}$ Department of Galenic Pharmacy and Food Technology, Complutense University of Madrid, Madrid, Spain, ${ }^{5}$ L'Albeitar, Guaso, Huesca, Spain
\end{abstract}

\section{OPEN ACCESS}

Edited by:

Domenico Bergero,

University of Turin, Italy

Reviewed by:

Margarita A. Arreguin Nava, Independent Researcher, Fayetteville Arkansas, United States

César Betancur,

Centro de Investigación y

Docencia, Colombia

Carlos Piñeiro,

PigCHAMP Pro Europa SL, Spain

*Correspondence:

Juan M. Rodríguez

jmrodrig@vet.ucm.es

Specialty section:

This article was submitted to Animal Nutrition and Metabolism, a section of the journa

Frontiers in Veterinary Science

Received: 11 February 2021 Accepted: 06 May 2021

Published: 31 May 2021

Citation Sobrino OJ, Alba C, Arroyo R, Pérez I, Sariego L, Delgado S, Fernández L, de María J, Fumanal P, Fumanal A and Rodríguez JM (2021) Replacement of Metaphylactic Antimicrobial Therapy

by Oral Administration of

Ligilactobacillus salivarius MP100 in a

Pig Farm. Front. Vet. Sci. 8:666887.

doi: 10.3389/fvets.2021.666887
Antibiotic use in swine production contributes to the emergence and spread of resistant bacteria, which poses a threat on human health. Therefore, alternative approaches must be developed. The objective of this work was the characterization of the probiotic properties of a Ligilactobacillus salivarius strain isolated from sow's milk and its application as an inoculated fermented feed to pregnant sows and piglets. The study was carried in a farm in which metaphylactic use of antimicrobials (including zinc oxide) was eliminated at the time of starting the probiotic intervention, which lasted for 2 years. Feces from 8-week-old piglets were collected before and after the treatment and microbiological and biochemical analyses were performed. The procedure led to an increase in the concentrations of clostridia and lactobacilli-related bacteria. Parallel, an increase in the concentration of butyrate, propionate and acetate was observed and a notable reduction in the presence of antibiotic resistant lactobacilli became apparent. In conclusion, replacement of antimicrobials by a microbiota-friendly approach was feasible and led to positive microbiological and biochemical changes in the enteric environment.

Keywords: swine, antimicrobials, antibiotic resistance, probiotics, Ligilactobacillus salivarius, short chain fatty acids, microbiome

\section{INTRODUCTION}

During the last decades, antibiotic-(multi)resistant bacteria have become a global threat for human health. The overuse, abuse and misuse of antibiotics in humans and animals have accelerated the development and spread of resistances. It has been suggested that the current "antibiotic resistance crisis" may lead us back to a "pre-antibiotic era" if effective actions to significantly decrease antibiotic use are not undertaken rapidly (1-4).

Prolonged prophylactic and metaphylactic use of antibiotics is widespread in intensive food animal management systems worldwide as low-cost growth promoters (5). The addition of sub-therapeutic levels of antibiotics in feed or water can improve growth rates by reducing the morbidity and mortality burden associated to bacterial diseases (6). However, such practice has notably contributed to the emergence and spread of resistant bacteria, both by direct contact with 
antibiotic-resistant bacteria from livestock or by indirect contact through food, water, and animal waste $(7,8)$. Swine production is responsible for a high proportion of the antimicrobials used in food animal production (6). Despite of the EU ban regarding the use of antibiotics as growth promoters, these antimicrobials have been frequently employed in the last years in swine farming as either prophylactic or metaphylactic agents. The spread of resistance to antibiotics will probably limit the therapeutic choices and increase morbidity and mortality rates due to porcine or human infections caused by resistant bacteria (3). A worrying example was the emergence of an Escherichia coli strain carrying a plasmid-mediated colistin-resistance gene in both people and pigs in China (9) and its rapid spread to these and other host species in Europe and North America (10-13). In addition to antibiotics, zinc oxide is another antimicrobial substance generally employed in swine production to try to prevent or minimize post-weaning diarrhea. Several alternatives have been suggested in order to replace routine use of prophylactic or metaphylactic antimicrobials in pig production, including acidifiers, prebiotics and probiotics.

In this context, the objectives of this work were, first, to isolate and characterize a probiotic candidate from milk of an in-house sow with a good record of reproductive outcomes; second, to apply the strain as strategy to replace routine metaphylactic use of antibiotics in the farm where the strain was isolated; third, to evaluate the microbiological and biochemical impact of that replacement strategy.

\section{MATERIALS AND METHODS}

\section{Isolation and Identification of $L$. salivarius MP100 From Porcine Milk}

Milk was collected as previously described (14) at day 14 after delivery from a healthy 7-years-old in-house sow with a good record of reproductive outcomes. The sample was kept frozen $\left(-20^{\circ} \mathrm{C}\right)$ until delivery to the laboratory. The sample was diluted in peptone water, $100 \mu \mathrm{L}$ of the dilutions were spread on Man, Rogosa, and Sharpe (MRS; Oxoid, Basingstoke, United Kingdom) agar plates supplemented with L-cysteine (0.5 g/L) (MRS-Cys) and incubated aerobically at $37^{\circ} \mathrm{C}$ for $48 \mathrm{~h}$. Only two colony morphologies were observed on the plates; one representative of each was selected and transferred to MRS broth tubes, which were incubated overnight under the same conditions without agitation. The isolate that reached the highest density $(\sim 9$ $\log _{10} \mathrm{CFU} / \mathrm{mL}$ ) was identified as L. salivarius by $16 \mathrm{~S}$ rRNA gene sequencing following the procedure described by Kullen et al. (15).

\section{Survival of $L$. salivarius MP100 After Exposition to Conditions Similar to Those of the Porcine GIT}

L. salivarius MP100 was tested using portions of a commercial antibiotic-free swine feed $(50 \mathrm{~g})$ containing $\sim 10^{9} \mathrm{CFU} / \mathrm{mL}$ of the strain in an in vitro model simulating passage through the oral cavity, the stomach and the small intestine, as described by Marteau et al. (16) with the modifications included by Martín et al. (17), using porcine gastric juice $(5 \mathrm{~mL}$; chloride: $129 \mathrm{mmol} / \mathrm{L}$; sodium: $68 \mathrm{mmol} / \mathrm{L} ; \mathrm{pH}$ 3.4) obtained in an abattoir (Madrid Norte, San Agustín de Guadalix, Madrid, Spain). The $\mathrm{pH}$ curve in the stomach-resembling compartment was controlled as described for monogastric mammals (18). After $120 \mathrm{~min}$ of total exposition, bacterial survival was determined by plating the samples onto MRS agar plates, which were anaerobically incubated at $37^{\circ} \mathrm{C}$ for $48 \mathrm{~h}$. Lacticaseibacillus rhamnosus GG, a well-characterized probiotic strain was used as a control because of its high survival rate in the same in vitro model (17).

\section{Determination of the Antimicrobial Activity and Antimicrobial Compounds Produced by L. salivarius MP100}

An overlay method (19) was used to determine the ability of L. salivarius MP100 to inhibit the growth of various bacterial species. The strain was inoculated ( $\sim 2$-cm-long lines) on MRS agar plates and incubated at $32^{\circ} \mathrm{C}$ for $48 \mathrm{~h}$ in anaerobic jars (Oxoid). Then, the indicator microorganisms $\left(\sim 10^{4} \mathrm{CFU}\right)$ vehiculated in $10 \mathrm{~mL}$ of soft $(0.7 \%$ agar) BHI (Oxoid) were inoculated on top. The bacteria employed as indicator organisms (our own culture collection) were originally isolated from feces of pigs or piglets with gastroenteritis (mainly diarrhea), septicemia, arthritis or meningitis symptoms, and included Clostridium perfringens MP34, Enterococcus faecalis MP42, Staphylococcus aureus MP83, Streptococcus suis MP205, Trueperella pyogenes MP214, Escherichia coli MP73 (F4) and MP77 (F18), Salmonella enterica serovar Typhimurium MP55, and Klebsiella pneumoniae MP87. The plates overlaid with bacterial indicators were further incubated according to the optimal growth temperature of the indicator microorganism $\left(32\right.$ or $\left.37^{\circ} \mathrm{C}\right)$ for $48 \mathrm{~h}$. Finally, the clear zones of inhibition $(>2 \mathrm{~mm}$ ) around the strain streaks were measured. All experiments assaying inhibitory activity were performed in triplicate.

Subsequently, the concentrations of L- and D-lactic acid in the supernatants obtained from MRS cultures (incubated for $16 \mathrm{~h}$ at $37^{\circ} \mathrm{C}$ ) of $\mathrm{L}$. salivarius MP100 were determined with an enzymatic kit (Roche Diagnostics, Mannheim, Germany), following the manufacturer's instructions. The $\mathrm{pH}$ values of the supernatants were also measured. The ability of $L$. salivarius MP100 to produce bacteriocins was determined in culture supernatants by the agar well diffusion assay described by Dodd et al. (20) and modified by Martín et al. (21), using as indicator bacteria the Gram-positive strains employed for the overlay method. The Gram-positive strains listed above for the initial screening for antimicrobial activity were employed as indicators of bacteriocinogenic activity. Since L. salivarius MP100 showed bacteriocinogenic activity against some of the indicators, PCR assays were performed to detect the structural genes corresponding to the L. salivarius bacteriocins salivaricin $\mathrm{B}$ and bacteriocin Abp-118 produced by this bacterial species, following the procedures described by Çataloluk (22) and Flynn et al. (23), respectively. 


\section{Adherence to Epithelial Cells and Porcine Mucin}

The adherence of L. salivarius MP100 to HT-29 and Caco-2 cells was examined as described by Coconnier et al. (24). The adhesion of bacterial cells of this strain to porcine mucin was determined according to the procedure reported by Cohen and Laux (25) and the modifications of Olivares et al. (26). The assays were performed in triplicate and the values were expressed as the mean $( \pm$ SD) number of adherent cells in 20 random microscopic fields. L. rhamnosus GG was used as a control strain in these assays because of its high adherence to these epithelial cells and to porcine mucin (17).

\section{Safety-Related Characterization of L. salivarius MP100}

The sensitivity of $L$. salivarius MP100 to antibiotics was determined by the E-test (BioMèrieux) using the cut-off levels established by EFSA for the antibiotics indicated for this species (27). The potential of $L$. salivarius MP100 to degrade partially purified porcine gastric mucin (HGM; Sigma) in vitro was evaluated following the plate procedure developed by Zhou et al. (28). Other safety-related analysis included the study of potential hemolysis using fresh horse blood agar plates (29), and the ability of the strain to produce biogenic amines (cadaverine, putrescine, histamine, and tyramine) from their respective precursor amino acids (30). These assays were performed in triplicate.

\section{Suppression of Metaphylactic Antibiotherapy in an Intensive Swine Farm and Replacement by Oral Administration of L. salivarius MP100 \\ General Design and Sampling}

The trial was conducted in an industrial closed cycle pig farm with a farrow-to-finish herd of 210 genetically similar Large White $\times$ Landrace sows. Sows, weaning piglets and fattening pigs were kept in high-investment indoor facilities following the UE standards requirements for animal welfare. Strict biosecurity protocols are followed on the farm, so that any animal or outsider is prevented from entering the production areas. Production farm management includes a 3-week batch system with an "all-in, all-out" procedure, with extensive cleaning followed by a sanitary break dry period of seven days between different batches. Piglets are weaned at 4 weeks of age. Until a few months before the starting of the assay, the farm had applied routine metaphylactic treatment during the perinatal period, consisting of the feed administration of zinc oxide, amoxicillin and colistin at the doses and for the periods of time prescribed by the veterinarian and recommended in the marketing authorization of authorized premixes for medicated feeding stuffs. Following the recommendations of the health authorities, the use of antimicrobials was eliminated gradually, starting with colistin and finishing with zinc oxide. The assay described below started once all the antimicrobials had been withdrawn.

From day 0 (sampling time T1), the diet of the animals was exactly the same that they were receiving before with the only exception that all antimicrobials (including zinc oxide) were completely removed from the feed. In addition, the strain L. salivarius MP100 was orally administered $\left(\sim 9 \log _{10}\right.$ CFU daily) to pregnant sows (during the week previous to farrowing and throughout the lactation period) and, also, to piglets continuously from 12 days after birth to the start of the fattening stage, through an inoculated fermented feed (IFF). This specific strain dose was selected because it has been shown to be efficient to modulate the host microbiota in previous clinical trials involving other L. salivarius strains $(31,32)$. This probiotic supplementation was carried out continuously in the farm for 2 years (sampling time T2). No control or placebo batches were included during the assay to avoid unintentionally transfer of the strain from treated to untreated animals. At sampling times T1 and T2, fecal samples from 15 different randomly-selected 8week-old piglets were collected in sterile containers directly from the rectum with the aid of sterile gloves and spatula, aliquoted ( 2 aliquots of $\sim 10 \mathrm{~g}$ ), and stored at $-20^{\circ} \mathrm{C}$ until processed as described below.

All animals were treated in strict accordance with the guidelines of the European Directive 2010/63/UE on the protection of animals used for scientific purposes. The study was approved by Ethical Committee on Animal Experimentation of the Faculty of Veterinary of the Universidad Complutense de Madrid (Spain), under protocol 33/17.

\section{Analysis of SCFAs}

Analysis of SCFAs (acetate, propionate, and butyrate) was performed using a dilution gas chromatography-mass spectrometry (GC-MS) assay as previously described $(33,34)$.

\section{Assessment of the Fecal Lactobacillus Population by Culture-Dependent Methods}

Fecal samples collected during the trial were serially diluted, plated onto MRS-Cys plates and incubated anaerobically (85\% nitrogen, $10 \%$ hydrogen, $5 \%$ carbon dioxide) in an anaerobic workstation (DW Scientific, Shipley, UK) for up to $72 \mathrm{~h}$ at $37^{\circ} \mathrm{C}$. After incubation, the number of colonies were recorded and at least one representative of each colony morphology was selected from the agar plates. The isolates were identified by Matrix Assisted Laser Desorption Ionization-Time of Flight (MALDI-TOF) mass spectrometry (Bruker, Germany). When the identification by MALDI-TOF was not possible at the species level (particularly in the case of lactobacilli isolates), the identification was carried out by $16 \mathrm{~S}$ ribosomal RNA (rRNA) gene sequencing as described by Mediano et al. (35).

The isolates identified as Limosilactobacillus reuteri, Lactobacillus johnsonii, and Lactobacillus amylovorus were genotyped by RAPD profiling as described (36). The sensitivity of one representative of each different genotype to antibiotics was determined by the E-test (BioMèrieux) using the cut-off levels established by the EFSA for the antibiotics indicated for these species (27). Finally, a subset of 14 strains was assessed for the presence of genes conferring transmissible resistance to erythromycin (ermB) and tetracycline (tet $W$ and tet $L$ ) as described in previous works $(37,38)$. 


\section{DNA Extraction From the Samples}

Approximately $1 \mathrm{~g}$ of each fecal sample was used for DNA extraction following a method described previously (39). Extracted DNA was eluted in $22 \mu \mathrm{L}$ of nuclease-free water and stored at $-20^{\circ} \mathrm{C}$ until further analysis. Purity and concentration of each extracted DNA was initially estimated using a NanoDrop 1000 spectrophotometer (NanoDrop Technologies, Inc., Rockland, USA). Negative controls (blanks) were processed in parallel.

\section{Real-Time Quantitative PCR Assays for the Specific Detection and Quantification of $L$. salivarius and L. reuteri DNA}

Quantification of L. salivarius and L. reuteri DNA was carried using the procedures described by Harrow et al. (40) and Haarman and Knol (41), respectively. The DNA concentration of all samples was adjusted to $5 \mathrm{ng} / \mu \mathrm{L}$. A commercial real-time PCR thermocycler (CFX96 $^{\mathrm{TM}}$, Biorad Laboratories, Hercules, CA, USA) was used for all experiments. Standard curves using 1:10 DNA dilutions (ranging from $2 \mathrm{ng}$ to $0.2 \mathrm{pg}$ ) from $L$. salivarius CECT5713 and L. reuteri MP07 (our own collection) were used to calculate the concentrations of the unknown bacterial genomic targets. Threshold cycle $(\mathrm{Ct})$ values between 15.29 and 20.07 were obtained for this range of bacterial DNA $\left(R^{2} \geq 0.992\right)$. The Ct values measured for DNA extracted from a non-target species (Lactiplantibacillus plantarum MP02; our own collection) was $\geq 39.27 \pm 0.64$. This control strain was selected because it is closely related, from a taxonomical point of view, to L. salivarius and $L$. reuteri (42). All samples and standards were run in triplicate.

\section{Metataxonomic Analysis}

The V3-V4 hypervariable region of the $16 \mathrm{~S}$ rDNA was amplified by PCR using the universal primers S-D-Bact-0341-b-S-17 (CCTACGGGNGGCWGCAG) and S-D-Bact-129 0785-a-A-21 (GACTACHVGGGTATCTAATCC) (43) and sequenced in the MiSeq system of Illumina at the facilities of Parque Científico de Madrid (Tres Cantos, Spain). Barcodes appended to 3' and 5 ' terminal ends of the PCR amplicons allowed separation of forward and reverse sequences in a second PCR-reaction. DNA concentration of the PCR products was quantified in a 2100 Bioanalyzer system (Agilent, Santa Clara, CA, USA). After pooling the PCR products at about equal molar ratios, DNA amplicons were purified by using a QIAEX II Gel Extraction Kit (Qiagen) from the excised band having the correct size after running on an agarose gel. DNA concentration was then quantified with PicoGreen (BMG Labtech, Jena, Germany). The pooled, purified and barcoded DNA amplicons were sequenced using the Illumina MiSeq pair-end protocol (Illumina Inc., San Diego, CA, USA) following the manufacturer's protocols.

\section{Bioinformatic Analysis}

Raw sequence data were demultiplexed and quality filtered using Illumina MiSeq Reporter analysis software. Microbiome bioinformatics was done with QIIME 22019.1 (44). Denoising was performed with DADA2 (45). The forward reads were truncated at position 285 by trimming the last 15 nucleotides while the reverse ones were truncated at the 259 nucleotides by trimming the last 10 nucleotides. Taxonomy was assigned to amplicon sequence variants (ASVs) using the q2-feature-classifier (46) and the naïve Bayes classifier classify-sklearn against the SILVA database version 138 (47). Posterior bioinformatic analysis was conducted using the $\mathrm{R}$ version 3.5.1 (R Core Team, 2013; https://www.R-project.org). The decontam package was used in order to identify, visualize and remove contaminating DNA with the concentration of extracted DNA. The 5 most-abundant phyla and the 19 most abundant genera from all the milk samples were selected for comparison between groups of samples.

\section{Statistical Analysis}

The sample size required to detect a difference of $1 \log _{10} \mathrm{CFU} / \mathrm{g}$ in the mean value of fecal lactobacilli counts between samples taken before (T1) and after (T2) the probiotic treatment in the pig farm and of $2 \log _{10} \mathrm{CFU} / \mathrm{g}$ in the mean value of fecal lactobacilli counts between samples taken after the probiotic treatment in the pig farm (T2) and samples from the control farm (C; an intensive pig farm in which routine metaphylactic treatment was routinely used) was calculated using $G^{*}$ Power 3.1.5 (48). Preliminary data indicated a great variation in the fecal lactobacilli counts in pig fecal samples $\left(1.25 \log _{10} \mathrm{CFU} / \mathrm{g}\right)$ which, given the magnitude of the difference to detect, rendered an effect size of 0.63 . The study would require 30 samples, equally distributed into two groups (T1 and T2), using a one-way ANOVA test at 5\% level of significance and a statistical power of $95 \%$.

Normally distributed data are reported as means and 95\% confidence intervals (CI) or as means and standard deviations (SD), and non-normally distributed data by medians and interquartile ranges (IQR). Exploratory multifactorial or two-way ANOVA tests were performed to assess globally the impact of the supplementation with the probiotic strain. One-way ANOVA tests were used to compare the mean values of the different variables between the three groups of pigs. Tukey's HSD posthoc tests were performed when required to identify which specific group's means were different after comparing all pairs of means. $t$-Tests allowed comparing the changes between the mean values of different parameters at the beginning and to the end of the probiotic assay. For non-normally distributed data, differences between groups were assessed using Kruskal-Wallis tests and pairwise Wilcoxon rank sum tests to compare data between farms. Bonferroni corrections were made to control for multiple comparisons. Statistical analysis and plotting were performed either using Statgraphics Centurion XVIII version 18.1.06 (Statgraphics Technologies, Inc., The Plains, VA, USA) or in the R environment and ggplot2. Differences were considered statistically significant at $p<0.05$.

\section{RESULTS}

\section{Isolation and Identification of the Strain From the Porcine Milk Sample}

Identification by $16 \mathrm{~S}$ rRNA gene sequencing of the isolate that showed the best growth revealed that it belonged to the species Ligilactobacillus salivarius and the nomenclature MP100 was ascribed to the strain. This species was previously known 
TABLE 1 | Antimicrobial activity of neutralized culture supernatants of $L$. salivarius MP100 (dimeter of the halos in cm).

\begin{tabular}{|c|c|c|}
\hline Indicator & $\begin{array}{l}\text { Overlaid } \\
\text { method }\end{array}$ & $\begin{array}{l}\text { Well } \\
\text { diffusion } \\
\text { assay }\end{array}$ \\
\hline $\begin{array}{l}\text { Enterococcus faecalis } \\
\text { MP42 }\end{array}$ & 0.8 & 0.7 \\
\hline $\begin{array}{l}\text { Clostridium perfringens } \\
\text { MP34 }\end{array}$ & 1.9 & 1.8 \\
\hline $\begin{array}{l}\text { Staphylococcus aureus } \\
\text { MP83 }\end{array}$ & 2.1 & 2.2 \\
\hline $\begin{array}{l}\text { Streptococcus suis } \\
\text { MP205 }\end{array}$ & 0.7 & 0.6 \\
\hline $\begin{array}{l}\text { Trueperella pyogenes } \\
\text { MP214 }\end{array}$ & 1.1 & 1.0 \\
\hline Escherichia coli MP73 (F4) & 2.9 & $\mathrm{Nd}$ \\
\hline $\begin{array}{l}\text { Escherichia coli MP77 } \\
\text { (F18) }\end{array}$ & 3.1 & $\mathrm{Nd}$ \\
\hline $\begin{array}{l}\text { Salmonella enterica } \\
\text { serovar Typhimurium } \\
\text { MP55 }\end{array}$ & 3.2 & $\mathrm{Nd}$ \\
\hline $\begin{array}{l}\text { Salmonella cholerasuis } \\
\text { CECT409 }\end{array}$ & 2.7 & $\mathrm{Nd}$ \\
\hline $\begin{array}{l}\text { Salmonella cholerasuis } \\
\text { CECT443 }\end{array}$ & 2.4 & $\mathrm{Nd}$ \\
\hline $\begin{array}{l}\text { Salmonella enteritidis } \\
\text { CECT4396 }\end{array}$ & 2.8 & $\mathrm{Nd}$ \\
\hline $\begin{array}{l}\text { Klebsiella pneumoniae } \\
\text { MP87 }\end{array}$ & 3.0 & $\mathrm{Nd}$ \\
\hline $\begin{array}{l}\text { Klebsiella pneumoniae } \\
\text { CECT } 142\end{array}$ & 3.2 & $\mathrm{Nd}$ \\
\hline
\end{tabular}

Nd, not detected.

as Lactobacillus salivarius but the name changed following the recent reclassification of the species within the genera Lactobacillus and Leuconostoc (49), and it is included in the QPS list of microorganisms with qualified presumption of safety of the European Food Safety Authority (EFSA) (50).

\section{Survival of $L$. salivarius MP100 After Exposition to Conditions Similar to Those Found in the Porcine Gastrointestinal Tract}

L. salivarius MP100 showed a significant survival rate under simulated porcine GIT conditions. Exposure to a saliva-like solution had no negative effect on the strain while the survival rate after the transit through the stomach- and small intestine-like compartments was $\sim 45 \%$ of the population initially inoculated. This value was comparable to that of the wellcharacterized probiotic strain L. rhamnosus GG (41\%).

\section{Antimicrobial Activity of $L$. salivarius MP100}

L. salivarius MP100 showed a noticeable inhibitory antimicrobial activity (inhibition zone $>0.5 \mathrm{~cm}$ around the streaks) against all indicator organisms used in this study (Table 1). This
TABLE 2 | Minimum inhibitory concentrations (MICs) and cut-off values ( $\mu \mathrm{g} / \mathrm{ml})$ for the antibiotics included within the EFSA criteria (27) for L. salivarius MP100.

\begin{tabular}{lcc}
\hline Antibiotics & Cut-off values & MICs (L. salivarius MP100) \\
\hline Ampicillin & 4 & 0.5 \\
Clindamycin & 4 & 0.5 \\
Chloramphenicol & 4 & 2 \\
Erythromycin & 1 & 0.5 \\
Streptomycin & 64 & 32 \\
Gentamicin & 16 & 2 \\
Kanamycin & 64 & 128 \\
Tetracycline & 8 & 2 \\
Vancomycin & n.r. & $>128$
\end{tabular}

n.r., not required.

antibacterial effect was particularly effective against the Gramnegative indicator strains because of their sensitivity to the low $\mathrm{pH}$ of the L. salivarius MP100 supernatants, which is a result of the production of lactic acid. In fact, neutralization of the strain culture $\mathrm{pH}$ led to loss of the antimicrobial activity against the Gram-negative indicators while remaining unaffected for the Gram-positives. L. salivarius MP100 exclusively produced the L-lactic acid isomer, which reached a concentration of 10.29 $( \pm 0.31) \mathrm{mg} / \mathrm{mL}$ (pH 3.92) after growth in MRS broth for $16 \mathrm{~h}$ at $37^{\circ} \mathrm{C}$. The production by L. salivarius CECT9145 [a high acidifying strain used as a control (16)] was $10.09( \pm 0.45)$ $\mathrm{mg} / \mathrm{mL}$ (pH 3.97). L. salivarius MP100 showed bacteriocinogenic activity against some of the Gram-positive indicator bacteria (Table 1) although it did not harbor the structural genes encoding salivaricins B, OR-7 or Abp118. This suggests that this strain produces a novel bacteriocin.

\section{Adherence of $L$. salivarius MP100 to Epithelial Cells and Porcine Mucin}

L. salivarius MP100 was strongly adhesive to both Caco-2 and HT-29 cell cultures. The mean \pm SD number of adherent cells in 20 random microscopic fields was $351.4 \pm 99.3$ and $844.6 \pm 137.8$ in Caco-2 and HT29 cells, respectively. These values were similar to those achieved by L. rhamnosus GG (361.6 \pm 108.9 and 820.2 \pm 150.4 , respectively). L. salivarius MP100 strongly adhered to porcine mucin since $\sim 12.7 \%$ of the fluorescence was retained in the wells after the washing steps of the assay. This value was higher than that obtained for L. rhamnosus GG $(9.57 \pm 1.46)$.

\section{Safety Characterization of $L$. salivarius MP100}

L. salivarius MP100 was susceptible to all antibiotics included within the EFSA criteria (27), with the exception of kanamycin (MIC: $128 \mu \mathrm{g} / \mathrm{mL}$; EFSA cut-off value: $64 \mu \mathrm{g} / \mathrm{mL}$ ) (Table 2). However, recent reports indicate that $L$. salivarius is intrinsically resistant to kanamycin $(29,51-54)$ due to lack of a transport system for this antibiotic (55). Moreover, L. salivarius MP100 was not hemolytic, was unable to degrade gastric mucin and did not produce biogenic amines in vitro. 
TABLE 3 | Microbiological and biochemical parameters, expressed as mean $( \pm \mathrm{SD})$, in the feces of 8-week-old piglets $(n=15)$ in the farm under study before (T1) and after 2 years (T2) of supplementation with L. salivarius MP100.

\begin{tabular}{lccc}
\hline Parameter & T1 & T2 & p-value \\
\hline Colony-forming units $\left(\log _{\mathbf{1 0}} \mathbf{C F U / g )}\right.$ & & & \\
Total Lactobacillaceae & $7.05(0.51)$ & $8.95(0.30)$ & $<0.001$ \\
L. salivarius & $2.63(0.45)$ & $4.30(0.98)$ & 0.006 \\
L. reuteri & $6.59(0.50)$ & $8.40(0.33)$ & $<0.001$ \\
L. johnsonii & $5.28(0.57)$ & $5.14(0.66)$ & 0.603 \\
L. amylovorus & $4.66(0.48)$ & $4.57(0.51)$ & 0.692 \\
qPCR (DNA copies/g) & & & \\
L. salivarius & $2.58(0.63)$ & $4.14(1.41)$ & 0.031 \\
L. reuteri & $6.78(0.62)$ & $8.47(0.45)$ & $<0.001$ \\
Short chain fatty acids $(\mathbf{m g} / \mathbf{g})$ & & & \\
Butyrate & $0.38(0.06)$ & $0.52(0.05)$ & $<0.001$ \\
Acetate & $2.86(0.14)$ & $3.24(0.25)$ & $<0.001$ \\
Propionate & $1.23(0.05)$ & $1.40(0.05)$ & $<0.001$ \\
\hline
\end{tabular}

\section{Suppression of Metaphylactic Antimicrobial Therapy in an Intensive Swine Farm With Replacement by Oral Administration of $L$. salivarius MP100}

L. salivarius MP100 was administered ( $\sim 9 \log _{10}$ colony-forming units (CFU)/day) to pregnant sows (from the week before farrowing to the end of the lactation period) and to piglets (from day 12 after birth to day 15 after weaning) through an inoculated fermented feed (IFF). At the start of the IFF treatment, all antimicrobial supplementation was retired and only individual injectable treatments were applied when required. The treatment was systematically applied for a 2-year period.

The IFF administration of the putative probiotic strain led to substantial microbiological changes in the piglet feces over time. The total mean $( \pm S D)$ microbial counts found by culture analysis in a subset of 8 -week-old piglets tested before the start of the treatment (sampling time T1) was 7.05 (0.51) $\log _{10} \mathrm{CFU} / \mathrm{g}$ while in a similar subset, placed in the same box 2 years later (sampling time T2) it raised to $8.95 \quad(0.30) \log _{10}$ CFU/g. L. reuteri (formerly $L$. reuteri), $L$. johnsonii and $L$. amylovorus were the dominant Lactobacillaceae species found in the samples at T1 and T2. However, L. salivarius and $L$. reuteri counts significantly increased after 2 years of probiotic treatment (Table 3). Analysis by $\mathrm{qPCR}$ also revealed a significant increase of $L$. salivarius and L. reuteri DNA.

The L. reuteri, L. johnsonii, and L. amylovorus isolates from T1 samples showed a high rate of antibiotic resistance, especially for tetracycline $(100 \%$ for the L. johnsonii and L. amylovorus and $>87.5 \%$ for the L. reuteri isolates) (Table 4 ). This last antibiotic was used in the farm under study until the sampling time T1. Interestingly, the antibiotic resistance rates sharply decreased after 2 years of antimicrobials withdrawal and concurrent probiotic treatment. In the case of tetracycline, it fell to $37.5,25$, and $12.5 \%$ for the L. reuteri, L. johnsonii, and
L. amylovorus isolates, respectively. Similarly, the resistance rates for ampicillin, clindamycin, chloramphenicol and erythromycin dropped to $0 \%$ of the $L$. reuteri and L. johnsonii isolates (Table 4). The search for genes conferring resistance to tetracycline (tet $L$, tet $W$ ) and erythromycin (ermB), detected erm $B$ and tet $W$ in some $\mathrm{T} 1$ isolates. In contrast, none of these genes were harbored by the isolates pertaining to the T2 samples.

The concentrations of SCFAs (acetate, propionate and butyrate) were highest in the feces of T2 piglets (Table 3 ). The differences between the T1 and T2 samples were statistically significant for all SCFAs.

The 16S rRNA gene-based metataxonomic analysis of the 45 fecal samples (15 from each group of piglets) yielded 4,606,781 high quality filtered sequences, ranging from 56,400 to 106,665 reads per sample [median $(\mathrm{IQR})=74,441 \quad(70,811-84,339)$ sequences per sample]. The Shannon index median was 4.02 (3.70-4.21) $(p<0.001)$ and $4.05(3.73-4.35)(p=0.008)$ for the $\mathrm{T} 1$ and $\mathrm{T} 2$ samples, respectively.

At the ASV level, the PCoA plots of the Bray-Curtis distance matrix (abundance) revealed that most of the samples clustered according to their origin (T1 and T2) (Figures 1, 2). The subsequent pairwise analysis of similarity (PERMANOVA) revealed that the differences between the two sets of samples were statistically significant for all pairwise comparisons $(p<$ 0.01). In the same way, differences were found in the Binnary Jaccard distance matrix (presence/absence) PCoA plot. Again, the samples clustered according to their origin $(p<0.01$ for all pairwise comparisons) (Figures 1, 2).

Firmicutes was the most abundant phylum in both sampling times (median (IQR) relative abundance of 90.9\% (89.8895.13\%) and 94.47\% (92.64-95.78\%), respectively; $p=0.348$ ) (Table 5). At the genus level, Clostridium was the most abundant both in the T1 and T2 samples but its abundance increased from T1 to T2 samples $(p<0.001)$ (Table 5). Parallel, the relative abundance of Turibacter, Romboutsia, and Lachnospiraceae was higher in T1 samples than in T2 samples $(p<0.001)$. In addition, the relative abundance of the genera Subdoligranulum, Ruminococcus, and Blautia (which also contains several SCFAsproducing species) and, also, that of the genus Streptococcus were significantly higher in T2 than in T1 samples (Table 5). In relation to Lactobacillus-related sequences, its abundance increased from T1 to T2 samples $(p=0.034)$.

\section{DISCUSSION}

In this work, the effects of the replacement of routine antimicrobial metaphylaxis by the oral administration of a putatively probiotic isolate of $L$. salivarius is described. The strain was obtained from the milk of a healthy sow with a record of reproductive excellence and was included in the feed of both sows and piglets, leading to a significant shift in the fecal metabolome and microbiota of 8 weeks-old piglets. The most relevant changes were the significant increases in the concentration of clostridia and the related SCFA metabolites (butyrate, acetate and propionate) that was accompanied by the improvement 
TABLE 4 | Antibiotic resistance rates (\%) among the L. reuteri, L. johnsonii, and L. amylovorus strains isolated from the feces of 8-week-old piglets in the study farm before (T1) and after 2 years of antibiotic withdrawal and supplementation with L. salivarius MP100 (T2).

\begin{tabular}{|c|c|c|c|c|c|c|}
\hline \multirow[b]{2}{*}{ Antibiotic } & \multicolumn{2}{|c|}{ L. reuteri } & \multicolumn{2}{|c|}{ L. johnsonii } & \multicolumn{2}{|c|}{ L. amylovorus } \\
\hline & T1 & T2 & T1 & T2 & T1 & T2 \\
\hline Ampicillin & 75 & 0 & 42 & 0 & 57 & 14 \\
\hline Clindamycin & 25 & 0 & 42 & 0 & 62.5 & 12.5 \\
\hline Chloramphenicol & 25 & 0 & 14 & 0 & 0 & 0 \\
\hline Erythromycin & 50 & 0 & 12.5 & 0 & 75 & 12.5 \\
\hline Streptomycin & 75 & 25 & 56 & 0 & 75 & 12.5 \\
\hline Gentamicin & 75 & 25 & 84 & 25 & 12.5 & 12.5 \\
\hline Kanamycin ${ }^{a}$ & 100 & 100 & 100 & 100 & 50 & 25 \\
\hline Tetracycline & 87.5 & 37.5 & 100 & 25 & 100 & 12.5 \\
\hline Vancomycin ${ }^{a}$ & 100 & 100 & 0 & 0 & 0 & 0 \\
\hline
\end{tabular}

The cut-off values were those established by EFSA (27).

${ }^{a}$ L. reuteri and L. johnsonii are intrinsically resistant to kanamycin. L. reuteri is intrinsically resistant to vancomycin [assays for these antibiotics and species are not required by EFSA (27)].

A

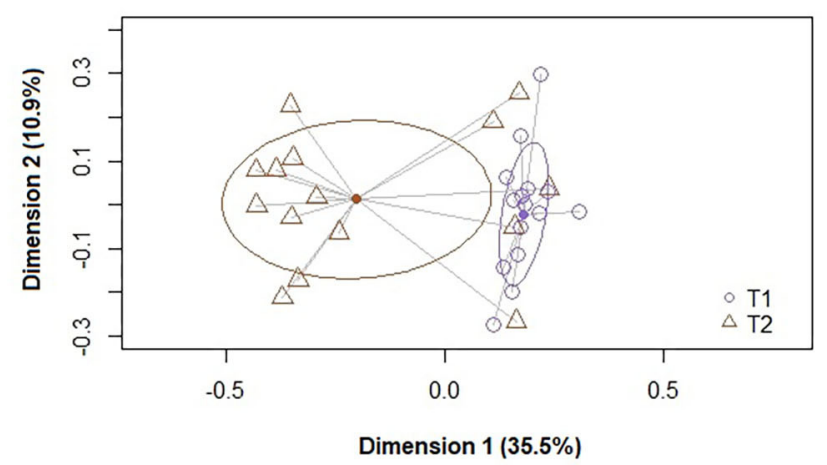

B

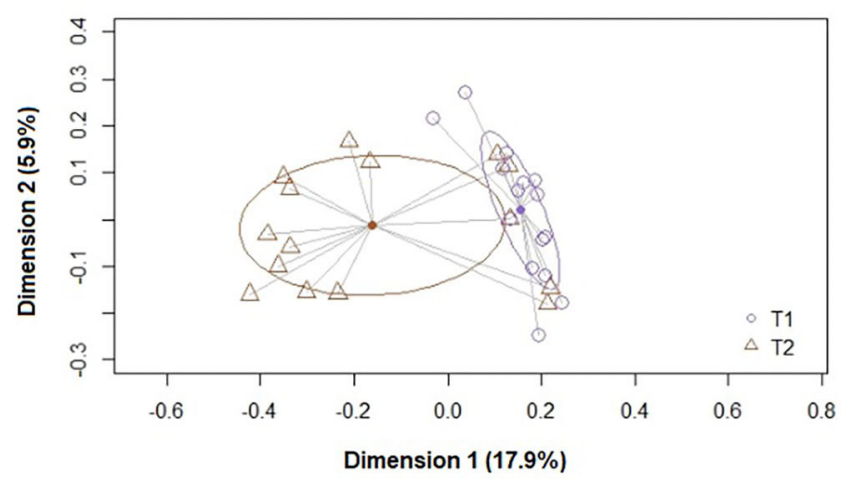

FIGURE 1 | Principal coordinate analysis (PCoA) plots of bacterial profiles at the genus level based on (A) the Bray-Curtis dissimilarity analysis (relative abundance) and (B) the Jaccard's coefficient for binary data (presence or absence). The values on each axis label represent the percentage of the total variance explained by that axis. The differences between the groups of fecal samples (T1, T2) were analyzed using the PERMANOVA test with 999 permutations.

of practically all the productivity parameters associated to this farming. As expected, there also was a significant increase in the concentration of Lactobacillus related bacteria.

Weaning transition is one of the most critical periods in intensive swine farming (56). Piglets are weaned at an age in which they should still be consuming sow's milk for some additional weeks and, therefore, neither their intestinal tract nor their immune system are fully developed (57). At the same time, they have to adapt to very stressful conditions (maternal separation, changes in diet and environment, mixing with new mates), a fact that usually leads to a temporary reduction in the feed intake and a post-weaning growth retardation (58). As a result, they become an easy target for "nosocomial" microbes that are highly prevalent in intensive farming, including pathogenic bacteria causing sepsis, meningitis, arthritis and gastrointestinal diseases. This is the reason why antibiotics were used as growth promoters and, although the European Union has banned them, they are still widely and routinely used as metaphylactic or false therapeutic agents.

Several approaches have been proposed to improve gut health that might allow antibiotic use discontinuation. In this context, the gut microbiota is considered a key factor in swine's health, due to its metabolic (including feed conversion efficiency) and immune differentiation roles and its contribution in preserving the integrity of the intestinal barrier (59-61). As a consequence, the intestinal microbiota exerts a strong influence on sow productivity $(62,63)$. Some of the beneficial effects associated to the gut microbiota are the result of specific bacterial metabolites, such as SCFAs, including acetate, propionate, and butyrate. SCFAs play several roles in the gut, from primary source of energy to colonocytes, immunomodulation and protection against pathogens to biosynthesis of mucus, and water and mineral absorption (64-66). 


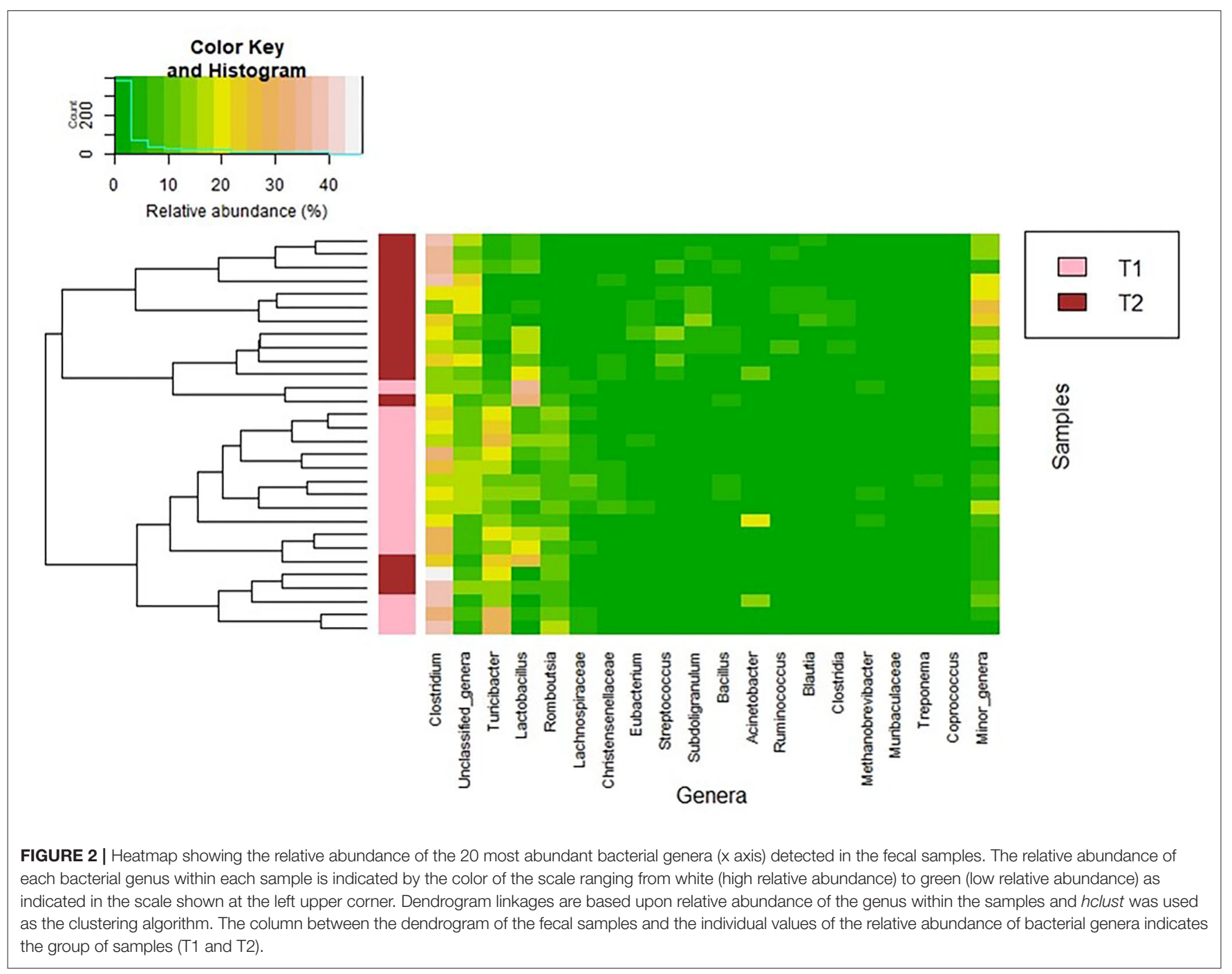

Among SCFAs, butyrate has attracted most research attention because of its additional beneficial effects on animal production, including the improvement of growth performance (67-71). Butyrate is the main end product of some non-pathogenic species of the genus Clostridium (72-74), which contribute to preserve a healthy intestinal microecology through the control of the growth of pathogenic microbes (75-77), while living in harmony with commensal members of the families Bacteroidaceae, Enterococcaceae, and Lactobacillaceae (77). In a previous study, the relative abundance of SCFA-producing bacteria and the concentrations of acetate, propionate and butyrate were significantly higher among fecal samples from highreproductive performance farms than among those from lowreproductive performance farms (78). Streptomycin treatment depleted butyrate-producing clostridia from the murine gut, decreased butyrate levels, and increased the population of pathogens like Salmonella enterica serovar Typhimurium (79). In contrast, direct administration of butyrate to pigs has shown to produce a variety of benefits to gut health, including the control of inflammation and the reinforcement of the barrier function
$(80,81)$. Such positive effects of butyrate may depend on the age of the animals and, therefore, in-feed supplementation should be performed as early as possible in order to obtain better health outcomes (82). Overall, any strategy resulting in an increased production of SCFAs (and particularly butyrate) will have a relevant role in the post-antibiotic era of animal production.

In this work, the abundance of Lactobacillus and Clostridium sequences increased simultaneous. This observation is not strange since both kinds of microbes usually establish a collaborative network in the porcine's gut. Lactobacilli decrease the intestinal $\mathrm{pH}$ and produce lactic acid, which is required by clostridia to produce butyrate. In turn, it has been repeatedly observed that butyrate-producing clostridia have the ability to inhibit pathogenic bacteria in the intestinal tract while promoting the growth of lactobacilli (83-85). It has been shown that severe damage in the epithelium of the ileum mucosa of pigs experimentally infected with Salmonella Typhimurium was correlated with a decrease of Lactobacillus and butyrate-producing anaerobic bacteria, including Clostridium spp. (86). 
TABLE 5 | Relative frequencies, medians and interquartile ranges (IQR) of the relative abundance (\%) of the most abundant bacterial phyla (in bold) and genera (in italics) detected in the T1 and T2 samples.

\begin{tabular}{|c|c|c|c|c|c|}
\hline \multirow[t]{2}{*}{ Phylum/genus } & \multicolumn{2}{|c|}{ T1 } & \multicolumn{2}{|c|}{$\mathrm{T} 2$} & \multirow[t]{2}{*}{$p$-value ${ }^{a}$} \\
\hline & $n^{\mathrm{b}}(\%)$ & Median (IQR) & $n(\%)$ & Median (IQR) & \\
\hline Firmicutes & 15 (100\%) & 90.9 (89.88-95.13) & 15 (100\%) & 94.47 (92.64-95.78) & 0.348 \\
\hline Bacteroidota & 15 (100\%) & $2.04(1.22-3.12)$ & 15 (100\%) & $2.43(1.50-3.59)$ & 1.000 \\
\hline Actinobacteriota & 15 (100\%) & $1.41(0.74-2.12)$ & 15 (100\%) & $1.20(0.91-1.77)$ & 1.000 \\
\hline Proteobacteria & 15 (100\%) & 0.07 (0.04-0.33) & $14(93 \%)$ & $0.03(0.01-0.07)$ & 0.110 \\
\hline Euryarchaeota & 15 (100\%) & $1.44(0.60-2.22)$ & 13 (87\%) & $0.50(0.13-0.85)$ & 0.054 \\
\hline Clostridium & 15 (100\%) & 12.07 (8.44-20.46) & 15 (100\%) & $22.9(19.23-36.66)$ & $<0.001$ \\
\hline Lactobacillus & 15 (100\%) & 7.68 (2.79-13.34) & 15 (100\%) & 8.84 (4.43-16.69) & 0.034 \\
\hline Turicibacter & 15 (100\%) & 18.42 (13.88-22.33) & 15 (100\%) & $4.54(2.83-8.03)$ & $<0.001$ \\
\hline Romboutsia & 15 (100\%) & $10.63(8.66-12.11)$ & 15 (100\%) & $1.78(1.06-4.80)$ & $<0.001$ \\
\hline Subdoligranulum & 15 (100\%) & $0.13(0.04-0.20)$ & 14 (93\%) & $1.47(0.41-5.32)$ & 0.005 \\
\hline Eubacterium & 15 (100\%) & $1.34(0.86-2.24)$ & 15 (100\%) & $2.67(1.97-2.78)$ & 0.056 \\
\hline Lachnospiraceae & 15 (100\%) & $4.52(3.11-4.88)$ & 15 (100\%) & $0.86(0.36-1.67)$ & $<0.001$ \\
\hline Ruminococcus & 15 (100\%) & $0.33(0.26-0.56)$ & 15 (100\%) & $1.57(0.43-3.11)$ & 0.017 \\
\hline Bacillus & $14(93 \%)$ & $0.74(0.43-2.21)$ & 15 (100\%) & $0.84(0.43-3.54)$ & 1.000 \\
\hline Blautia & 15 (100\%) & $0.17(0.06-0.26)$ & $14(93 \%)$ & $0.80(0.15-2.99)$ & 0.044 \\
\hline Streptococcus & $8(53 \%)$ & $0.01(<0.01-0.03)$ & 15 (100\%) & $0.51(0.12-5.04)$ & $<0.001$ \\
\hline Mogibacterium & 15 (100\%) & $0.38(0.23-0.61)$ & 15 (100\%) & $0.29(0.19-0.58)$ & 1.000 \\
\hline Treponema & 15 (100\%) & $0.83(0.41-1.11)$ & 15 (100\%) & $0.31(0.14-0.59)$ & 0.180 \\
\hline
\end{tabular}

${ }^{a}$ Wilconson rank sum test.

${ }^{b} n(\%):$ number of samples in which the phylum/genus was detected (relative frequency of detection).

Lactobacilli are dominant bacteria in the pig gut microbiota during early life (87). Among the different Lactobacillus species, $L$. reuteri and $L$. salivarius are host-adapted species which share a long-term evolutionary history with swine $(88,89)$. In fact, they are among the few Lactobacillus species that can be isolated from mammalian milk, including sow's milk (14). As normal residents, this group of bacteria thus has an advantage over others in ecology for colonizing the gut. However, the normal process of acquisition of the piglet gut microbiota is greatly disrupted by the high social and physiological stress together with the abrupt interruption of the immune protection imposed by early weaning (90). Under such circumstances, the gut microbiota is characterized by a severe dysbiosis (91-93), with a sharp decrease of lactobacilli (93), and a high susceptibility to pathogen infection $(94,95)$. In this study, the administration of L. salivarius MP100 led to an increase of the Lactobacillus abundance. Culturedependent analysis and species-specific detection of $L$. salivarius and $L$. reuteri by qPCR indicated that the increase in the Lactobacillus abundance was not due to a sharp increase in the concentration of L. salivarius (which was actually moderate) but to a notable increase in the population of L. reuteri. It has been previously shown that the administration of a probiotic strain may have a low impact in terms of colonization of that probiotic strain but a high impact in relation to the promotion of the growth of other beneficial members of the gut microbiota (96).

A large number of in vivo studies have assessed the impact of different probiotic Lactobacillus on the performance and health of weaned piglets (97). However, the results have been very heterogeneous depending on the tested probiotic product and the posology. This highlights the need for a better selection and characterization of the strains aimed to be used as swine probiotics. Anyway, some probiotics have successfully improved the health and performance in neonatal and growing pigs (98100), including L. reuteri and L. salivarius strains (101-109).

The strategy followed in this work implied the administration of the probiotic strain to both sows and piglets. Previous studies have reported that providing sows and their piglets with the same strain simultaneously was more effective than feeding sows or piglets alone $(21,110-116)$.

As it has been stated above, both the use of butyrate and probiotics are usually considered among the potential candidates to substitute antibiotics. In this work, we have shown that the use of a well-characterized L. salivarius strain isolated from sow milk was able to drive a significant increase in the abundance of Lactobacillus and butyrate-producing clostridia, which resulted in significant increases in the concentration of the three assayed SCFAs, including butyrate.

This shift in the gut ecology of the treated animals was associated with a decrease in the prevalence of antibioticresistant lactobacilli. These microbes are good indicators of antibiotic pressure since they easily adapt to antibiotic-rich environments by different mechanisms, including the acquisition of transmissible genes $(117,118)$. This study shows that a 2 -year period of antibiotic withdrawal is enough to reduce notably the burden of antibiotic resistances in a pig farm, a fact that must be highlighted in the frame of the current antibiotic resistance crisis. In this study a high percentage of L. reuteri, L. johnsoni, and L. amylovorus strains showed phenotypic resistance against many 
of the tested antibiotics. Antibiotic resistances among lactobacilli can be intrinsic [e.g., changes in the composition of the cell wall, as in the case of the intrinsic resistance of many Lactobacillus species to vancomycin (119)] or acquired through chromosomal mutations [e.g., a single mutation in the $23 \mathrm{~S}$ rRNA gene reducing the affinity of erythromycin for the ribosome (120)]. The risk of inter-bacterial transfer of antibiotic resistances is insignificant for lactobacilli displaying intrinsic resistances or acquired resistances due to chromosomal mutations. In contrast, the potential of transmissible resistance genes (particularly those associated to mobile genetic elements) for horizontal spread is high and this risk deserves special attention because of its connotations for public health. In this context, several genes responsible for transmissible antibiotic resistance among lactobacilli have already been reported [reviewed in (118)].

Tetracycline resistance (tet) genes are the most common determinants of transmissible resistance in lactobacilli. It has been recently reported that the use of tetracycline selects the presence of transmissible genes conferring resistance not only to tetracycline (tet genes) but, also, to erythromycin (erm genes) in nursery pigs (121). As a consequence, such genes are widely spread in intensive pig farms using antibiotic metaphylactic approaches $(122,123)$. Presence of tet and erm genes seems to be relatively frequent among $L$. reuteri and $L$. johnsonii isolates from pork and poultry meat $(124,125)$, two of the farm sectors in which the use of antibiotics is particularly high. Sequencing of the tet $M$ genes from such origin has revealed that there are almost identical (>99\% sequence similarity) to tet $M$ genes previously identified in human pathogens (Neisseria meningitidis, Listeria monocytogenes) (124). With respect to lactobacilli, it is long known that transference of transmissible antibiotic resistance can occur in different directions: (a) between different lactobacilli species/strains; (b) from lactobacilli to different Gram-positive bacteria, including relevant human pathogens (e.g., Staphylococcus aureus); and (c) from other Gram-positive bacteria to lactobacilli (126-128). In fact, the prevalence of tet and erm genes is very high among staphylococci (including $S$. aureus and $S$. epidermidis) isolates in the different steps of the chain of swine production, which pose a considerable risk for consumers (129). The presence of antibiotic selective pressure enhances the transfer of these resistance determinants (130). Use, abuse or misuse of antibiotics in intensive food production systems increases the chances of transmission of antibiotic resistant bacteria from livestock to humans (131-133). In addition, routine zinc supplementation in the swine diet has also been identified as a factor contributing to increase and maintain the presence of tetracycline resistance genes in the porcine gut (134-136).

\section{REFERENCES}

1. Prescott JF. The resistance tsunami, antimicrobial stewardship, and the golden age of microbiology. Vet Microbiol. (2014) 171:273-8. doi: 10.1016/ j.vetmic.2014.02.035

2. D'Andrea MM, Fraziano M, Thaller MC, Rossolini GM. The urgent need for novel antimicrobial agents and strategies to fight antibiotic resistance. Antibiotics. (2019) 8:254. doi: 10.3390/antibiotics8040254
Although lactobacilli are usually sensitive to $\beta$-lactamases and the blaZ gene has been rarely detected among these microbes (124), resistance to ampicillin was high among the strains isolated in this study. Future work will involve genome sequencing of those strains displaying high phenotypic resistance against this and other antibiotics and harboring the 3 resistance genes assayed in this work (tetL, telW, ermB).

Overall our study shows that the replacement of antibiotics by other microbiota-friendly approaches was feasible and led to positive microbiological and biochemical shifts in the enteric environment.

\section{DATA AVAILABILITY STATEMENT}

The datasets presented in this study can be found in online repositories. The data presented in the study are deposited in the NCBI Short Read Archive repository, accession number PRJNA705469.

\section{ETHICS STATEMENT}

The animal study was reviewed and approved by Ethical Committee on Animal Experimentation of the Faculty of Veterinary of the Universidad Complutense de Madrid (Spain), protocol 33/17. Written informed consent for participation was not obtained from the owners because the owners (L'Albeitar) participated in the study and they are co-authors of this manuscript.

\section{AUTHOR CONTRIBUTIONS}

OS, PF, JM, AF, and JR designed and coordinated the study. OS, PF, JM, and AF designed the inoculated fermented feed. $\mathrm{PF}, \mathrm{JM}$, and AF administered the strain, collected the fecal samples and keep updated the farm database. RA, IP, and JR processed the samples and performed the microbiological and biochemical analyses. SD and LS analyzed the presence of antibiotic resistance genes among the lactobacilli strains. CA and LF executed bioinformatics and statistical analysis. JR drafted the manuscript. All authors contributed to the critical review of the manuscript and approved the final version submitted to this manuscript.

\section{ACKNOWLEDGMENTS}

We thank Prof. Evaristo Suárez (University of Oviedo, Spain) for critical reading of the manuscript and fruitful discussions. Report to the Secretary-General of the United Nations (2019).

4. Palma E, Tilocca B, Roncada P. Antimicrobial resistance in veterinary medicine: an overview. Int J Mol Sci. (2020) 21:1914. doi: 10.3390/ijms21061914

5. WHO. Antimicrobial Resistance: Global Report on Surveillance. Geneva: WHO (2014). 
6. Yang $\mathrm{H}$, Paruch $\mathrm{L}$, Chen $\mathrm{X}$, van Eerde A, Skomedal H, Wang Y, et al. Antibiotic application and resistance in swine production in China: current situation and future perspectives. Front Vet Sci. (2019) 6:136. doi: $10.3389 /$ fvets.2019.00136

7. Marshall BM, Levy SB. Food animals and antimicrobials: impacts on human health. Clin Microbiol Rev. (2011) 24:718-33. doi: 10.1128/CMR.00002-11

8. Landers TF, Cohen B, Wittum TE, Larson EL. A review of antibiotic use in food animals: perspective, policy, and potential. Public Health Rep. (2012) 127:4-22. doi: 10.1177/003335491212700103

9. Liu Y-Y, Wang T, Walsh TR, Yi L-X, Zhang R, Spencer J, et al. Emergence of plasmid-mediated colistin resistance mechanism MCR-1 in animals and human beings in China: a microbiological and molecular biological study. Lancet Infect Dis. (2016) 16:161-8. doi: 10.1016/S1473-3099(15)00424-7

10. Hasman H, Hammerum A, Hansen F, Hendriksen R, Olesen B, Agersø $\mathrm{Y}$, et al. Detection of $m c r-1$ encoding plasmid-mediated colistinresistant Escherichia coli isolates from human bloodstream infection and imported chicken meat, Denmark 2015. Euro Surveill. (2015) 20:50. doi: 10.2807/1560-7917.ES.2015.20.49.30085

11. McGann P, Snesrud E, Maybank R, Corey B, Ong AC, Clifford R, et al. Escherichia coli harboring $m c r-1$ and $b l a_{\mathrm{CTX}-\mathrm{M}}$ on a novel IncF plasmid: first report of $m c r-1$ in the USA. Antimicrob Agents Chemother. (2016) 60:4420-1. doi: 10.1128/AAC.01103-16

12. Haenni M, Poirel L, Kieffer N, Châtre P, Saras E, Métayer V, et al. Cooccurrence of extended spectrum $\beta$ lactamase and MCR-1 encoding genes on plasmids. Lancet Infect Dis. (2016) 6:281-2. doi: 10.1016/S1473-3099(16) 00007-4

13. Quesada A, Ugarte-Ruiz M, Iglesias MR, Porrero MC, Martínez R, FlorezCuadrado D, et al. Detection of plasmid mediated colistin resistance (MCR1) in Escherichia coli and Salmonella enterica isolated from poultry and swine in Spain. Res Vet Sci. (2016) 105:134-5. doi: 10.1016/j.rvsc.2016.02.003

14. Martín R, Delgado S, Maldonado A, Jiménez E, Olivares M, Fernández L, et al. Isolation of lactobacilli from sow milk and evaluation of their probiotic potential. J Dairy Res. (2009) 76:418-25. doi: 10.1017/S0022029909990124

15. Kullen MJ, Sanozky-Dawes RB, Crowell DC, Klaenhammer TR. Use of DNA sequence of variable regions of the 16SrRNA gene for rapid and accurate identification of bacteria in the Lactobacillus acidophilus complex. J Appl Microbiol. (2000) 89:511-8. doi: 10.1046/j.1365-2672.2000. 01146.x

16. Marteau P, Minekus M, Havenaar R, Huis In't Veld JHJ. Survival of lactic acid bacteria in a dynamic model of the stomach and small intestine: validation and the effects of bile. J Dairy Sci. (1997) 80:10317. doi: 10.3168/jds.S0022-0302(97)76027-2

17. Martín R, Olivares M, Marín ML, Fernández L, Xaus J, Rodríguez JM. Probiotic potential of 3 lactobacilli strains isolated from breast milk. J Hum Lact. (2005) 21:8-17. doi: 10.1177/0890334404272393

18. Conway PL, Gorbach SL, Goldin BR. Survival of lactic acid bacteria in the human stomach and adhesion to intestinal cells. J Dairy Sci. (1987) 70:1-12. doi: 10.3168/jds.S0022-0302(87)79974-3

19. Magnusson J, Schnürer J. Lactobacillus coryniformis subsp. coryniformis strain Si3 produces a broad-spectrum proteinaceous antifungal compound. Appl Environ Microbiol. (2001) 67:1-5. doi: 10.1128/AEM.67.1.1-5.2001

20. Dodd HM, Horn N, Zhang H, Gasson MJ. A lactococcal expression system for engineered nisins. Appl Environ Microbiol. (1992) 58:368393. doi: 10.1128/AEM.58.11.3683-3693.1992

21. Martín R, Olivares M, Marín ML, Xaus J, Fernández L, Rodríguez JM. Characterization of a reuterin-producing Lactobacillus coryniformis strain isolated from a goat's milk cheese. Int J Food Microbiol. (2005) 104:267-77. doi: 10.1016/j.ijfoodmicro.2005.03.007

22. Çataloluk O. Molecular characterization of the gene encoding for salivaricin B activity and its flanking sequences. Turk J Biol. (2001) 25:379-86.

23. Flynn S, van Sinderen D, Thornton GM, Holo H, Nes IF, Collins JK. Characterization of the genetic locus responsible for the production of ABP-118, a novel bacteriocin produced by the probiotic bacterium Lactobacillus salivarius subsp. salivarius UCC118. Microbiology. (2002) 148:973-84. doi: 10.1099/00221287-148-4-973

24. Coconnier MH, Klaenhammer TR, Kernéis S, Bernet MF, Servin AL. Protein-mediated adhesion of Lactobacillus acidophilus BG2FO4 on human enterocyte and mucus-secreting cell lines in culture. Appl Environ Microbiol. (1992) 58:2034-9. doi: 10.1128/AEM.58.6.2034-2039.1992

25. Cohen PS, Laux DC. Bacterial adhesion to and penetration of intestinal mucus in vitro. Methods Enzymol. (1995) 253:30914. doi: 10.1016/S0076-6879(95)53026-6

26. Olivares M, Díaz-Ropero MP, Martín R, Rodríguez JM, Xaus J. Antimicrobial potential of four Lactobacillus strains isolated from breast milk. J Appl Microbiol. (2006) 101:72-9. doi: 10.1111/j.1365-2672.2006.02981.x

27. EFSA. Guidance on the characterisation of microorganisms used as feed additives or as production organisms. EFSA J. (2018) 16:e05206. doi: 10.2903/j.efsa.2018.5206

28. Zhou JS, Gopal PK, Hill HS. Potential probiotic lactic acid bacteria Lactobacillus rhamnosus (HN001), Lactobacillus acidophilus (HN017) and Bifidobacterium lactis (HN019) do not degrade gastric mucin in vitro. Int J Food Microbiol. (2001) 63:81-90. doi: 10.1016/S0168-1605(00)00398-6

29. Martín V, Cárdenas N, Ocaña S, Marín M, Arroyo R, Beltrán D, et al. Rectal and vaginal eradication of Streptococcus agalactiae (GBS) in pregnant women by using Lactobacillus salivarius CECT 9145, a target-specific probiotic strain. Nutrients. (2019) 11:E810. doi: 10.3390/nu11040810

30. Bover-Cid S, Holzapfel WH. Improved screening procedure for biogenic amine production by lactic acid bacteria. Int J Food Microbiol. (1999) 53:3341. doi: 10.1016/S0168-1605(99)00152-X

31. Arroyo R, Martín V, Maldonado A, Jiménez E, Fernández L, Rodríguez JM. Treatment of infectious mastitis during lactation: antibiotics versus oral administration of lactobacilli isolated from breast milk. Clin Infect Dis. (2010) 50:1551-8. doi: 10.1086/652763

32. Fernández L, Cárdenas N, Arroyo R, Manzano S, Jiménez E, Martín V, et al. Prevention of infectious mastitis by oral administration of Lactobacillus salivarius PS2 during late pregnancy. Clin Infect Dis. (2016) 62:56873. doi: $10.1093 / \mathrm{cid} / \mathrm{civ} 974$

33. Moreau NM, Goupry SM, Antignac JP, Monteau FJ, Le Bizec BJ, Champ $\mathrm{MM}$, et al. Simultaneous measurement of plasma concentrations and 13Cenrichment of short-chain fatty acids, lactic acid and ketone bodies by gas chromatography coupled to mass spectrometry. J Chromat B. (2003) 784:395-403. doi: 10.1016/S1570-0232(02)00827-9

34. Guard BC, Barr JW, Reddivari L, Klemashevich C, Jayaraman A, Steiner JM, et al. Characterization of microbial dysbiosis and metabolomic changes in dogs with acute diarrhea. PLoS ONE. (2015) 10:e0127259. doi: 10.1371/journal.pone.0127259

35. Mediano P, Fernández L, Jiménez E, Arroyo R, Espinosa-Martos I, Rodríguez JM, et al. Microbial diversity in milk of women with mastitis: potential role of coagulase-negative staphylococci, viridans group streptococci, and corynebacteria. J Hum Lact. (2017) 33:30918. doi: $10.1177 / 0890334417692968$

36. Ruiz-Barba JL, Maldonado A, Jiménez-Díaz R. Small-scale total DNA extraction from bacteria and yeast for PCR applications. Anal Biochem. (2005) 347:333-5. doi: 10.1016/j.ab.2005.09.028

37. Rizzotti L, La Gioia F, Dellaglio F, Torriani S. Characterization of tetracyclineresistant Streptococcus thermophilus isolates from Italian soft cheeses. Appl Environ Microbiol. (2009) 75:4224-9. doi: 10.1128/AEM.01380-08

38. Delgado S, Fracchetti F, Mayo B, Torriani S. Development and validation of a multiplex PCR-based DNA microarray hybridisation method for detecting bacterial antibiotic resistance genes in cheese. Int Dairy J. (2011) 21:14957. doi: 10.1016/j.idairyj.2010.10.005

39. Lackey KA, Williams JE, Meehan CL, Zachek JA, Benda ED, Price WJ, et al. What's normal? Microbiomes in human milk and infant feces are related to each other but vary geographically: the INSPIRE study. Front Nutr. (2019) 6:45. doi: 10.3389/fnut.2019.00045

40. Harrow SA, Ravindran V, Butler RC, Marshall JW, Tannock GW. Real-time quantitative PCR measurement of ileal Lactobacillus salivarius populations from broiler chickens to determine the influence of farming practices. Appl Environ Microbiol. (2007) 73:7123-7. doi: 10.1128/AEM.01 289-07

41. Haarman M, Knol J. Quantitative real-time PCR analysis of fecal Lactobacillus species in infants receiving a prebiotic infant formula. Appl Environ Microbiol. (2006) 72:235965. doi: 10.1128/AEM.72.4.2359-2365.2006 
42. Salvetti E, Harris HMB, Felis GE, O'Toole PW. Comparative genomics of the genus Lactobacillus reveals robust phylogroups that provide the basis for reclassification. Appl Environ Microbiol. (2018) 84:e0099318. doi: 10.1128/AEM.02052-18

43. Klindworth A, Pruesse E, Schweer T, Peplies J, Quast C, Horn M, et al. Evaluation of general 16S ribosomal RNA gene PCR primers for classical and next-generation sequencing-based diversity studies. Nucleic Acids Res. (2013) 41:el. doi: 10.1093/nar/gks808

44. Bolyen E, Rideout JR, Dillon MR, Bokulich NA, Abnet CC, AlGhalith GA, et al. Reproducible, interactive, scalable and extensible microbiome data science using QIIME 2. Nat Biotechnol. (2019) 37:8527. doi: 10.1038/s41587-019-0209-9

45. Callahan BJ, McMurdie PJ, Rosen MJ, Han AW, Johnson AJ, Holmes SP. DADA2: High-resolution sample inference from Illumina amplicon data. Nat Methods. (2016) 13:581-3. doi: 10.1038/nmeth.3869

46. Bokulich NA, Kaehler BD, Rideout JR, Dillon M, Bolyen E, Knight $\mathrm{R}$, et al. Optimizing taxonomic classification of marker-gene amplicon sequences with QIIME 2's q2-feature-classifier plugin. Microbiome. (2018) 6:90. doi: 10.1186/s40168-018-0470-z

47. Quast C, Pruesse E, Yilmaz P, Gerken J, Schweer T, Yarza P, et al. The SILVA ribosomal RNA gene database project: improved data processing and web-based tools. Nucleic Acids Res. (2013) 41:D590596. doi: 10.1093/nar/gks1219

48. Faul F, Erdfelder E, Lang A-G, Buchner A. G* Power 3: a flexible statistical power analysis program for the social, behavioral, and biomedical sciences. Behav Res Methods. (2007) 39:175-91. doi: 10.3758/BF03193146

49. Zheng J, Wittouck S, Salvetti E, Franz C, Harris H, Mattarelli P, et al. A taxonomic note on the genus Lactobacillus: Description of 23 novel genera, emended description of the genus Lactobacillus Beijerinck 1901, and union of Lactobacillaceae and Leuconostocaceae. Int J Syst Evol Microbiol. (2020) 70:2782-858. doi: 10.1099/ijsem.0.004107

50. EFSA Panel on Biological Hazards (BIOHAZ). Scientific Opinion on the update of the list of QPS-recommended biological agents intentionally added to food feed as notified to EFSA. EFSA J. (2017) 15:4664. doi: 10.2903/j.efsa.2017.4884

51. Danielsen M, Wind A. Susceptibility of Lactobacillus spp. to antimicrobial agents. Int J Food Microbiol. (2003) 82:111. doi: 10.1016/S0168-1605(02)00254-4

52. Zhou JS, Pillidge CJ, Gopal PK, Gill HS. Antibiotic susceptibility profiles of new probiotic Lactobacillus and Bifidobacterium strains. Int J Food Microbiol. (2005) 98:211-7. doi: 10.1016/j.ijfoodmicro.2004.05.011

53. Klare I, Konstabel C, Werner G, Huys G, Vankerckhoven V, Kahlmeter G, et al. Antimicrobial susceptibilities of Lactobacillus, Pediococcus and Lactococcus human isolates and cultures intended for probiotic or nutritional use. J Antimicrob Chemother. (2007) 59:900-12. doi: 10.1093/jac/dkm035

54. Cárdenas N, Martín V, Arroyo R, López M, Carrera M, Badiola C, et al. Prevention of recurrent acute otitis media in children through the use of Lactobacillus salivarius PS7. A target-specific probiotic strain. Nutrients. (2019) 11:376. doi: 10.3390/nu11020376

55. Bryan LE, Kwan S. Mechanisms of aminoglycoside resistance of anaerobic bacteria and facultative bacteria grown anaerobically. $J$ Antimicrob Chemother. (1981) 8 (Suppl. D):1-8. doi: 10.1093/jac/8.suppl_D.1

56. Thacker PA. Alternatives to antibiotics as growth promoters for use in swine production: a review. J Anim Sci Biotechnol. (2013) 4:35. doi: 10.1186/2049-1891-4-35

57. Bailey M, Haverson K, Inman C, Harris C, Jones P, Corfield G, et al. The development of the mucosal immune system pre- and post-weaning: balancing regulatory and effector function. Proc Nutr Soc. (2005) 64:4517. doi: 10.1079/PNS2005452

58. Lallés JP, Boudry G, Favier C, Le Floch N, Luron I, Montagne L, et al. Gut function and dysfunction in young pigs: physiology. Anim Res. (2004) 53:301-16. doi: 10.1051/animres:2004018

59. Fouhse JM, Zijlstra RT, Willing BP. The role of gut microbiota in the health and disease of pigs. Anim Front. (2016) 6:30-6. doi: 10.2527/af.2016-0031

60. Yang $\mathrm{H}$, Huang $\mathrm{X}$, Fang $\mathrm{S}$, He $\mathrm{M}$, Zhao $\mathrm{Y}, \mathrm{Wu} \mathrm{Z}$, et al. Unraveling the fecal microbiota and metagenomic functional capacity associated with feed efficiency in pigs. Front Microbiol. (2017) 8:1555. doi: 10.3389/fmicb.2017.01555
61. McCormack UM, Curião T, Buzoianu SG, Prieto ML, Ryan T, Varley $\mathrm{P}$, et al. Exploring a possible link between the intestinal microbiota and feed effciency in pigs. Appl Environ Microbiol. (2017) 83:e0038017. doi: 10.1128/AEM.00380-17

62. Shao Y, Zhou J, Xiong X, Zou L, Kong X, Tan B, et al. Differences in gut microbial and serum biochemical indices between sows with different productive capacities during perinatal period. Front Microbiol. (2020) 10:3047. doi: 10.3389/fmicb.2019.03047

63. Xu K, Bai M, Liu H, Duan Y, Zhou X, Wu X, et al. Gut microbiota and blood metabolomics in weaning multiparous sows: associations with oestrous. $J$ Anim Physiol Anim Nutr. (2020) 104:1155-68. doi: 10.1111/jpn.13296

64. Namkung H, Yu H, Gong J, Leeson S. Antimicrobial activity of butyrate glycerides toward Salmonella Typhimurium and Clostridium perfringens. Poult Sci. (2011) 90:2217-22. doi: 10.3382/ps.2011-01498

65. Ma N, Guo P, Zhang J, He T, Kim SW, Zhang G, et al. Nutrients mediate intestinal bacteria-mucosal immune crosstalk. Front Immunol. (2018) 9:5. doi: 10.3389/fimmu.2018.00005

66. Bedford A, Gong J. Implications of butyrate and its derivatives for gut health and animal production. Anim Nutr. (2018) 4:151-9. doi: 10.1016/j.aninu.2017.08.010

67. Ma X, Fan PX, Li LS, Qiao SY, Zhang GL, Li DF. Butyrate promotes the recovering of intestinal wound healing through its positive effect on the tight junctions. J Anim Sci. (2012) 90 (Suppl. 4):266-8. doi: 10.2527/jas.50965

68. Gonçalves P, Martel F. Butyrate and colorectal cancer: the role of butyrate transport. Curr Drug Metab. (2013) 14:9941008. doi: 10.2174/1389200211314090006

69. Fang CL, Sun H, Wu J, Niu HH, Feng J. Effects of sodium butyrate on growth performance, haematological and immunological characteristics of weanling piglets. J Anim Physiol Anim Nutr. (2014) 98:680-5. doi: 10.1111/jpn.12122

70. van der Beek CM, Dejong CHC, Troost FJ, Masclee AAM, Lenaerts K. Role of short-chain fatty acids in colonic inflammation, carcinogenesis, and mucosal protection and healing. Nutr Rev. (2017) 75:286-305. doi: 10.1093/nutrit/nuw067

71. Simeoli R, Mattace Raso G, Pirozzi C, Lama A, Santoro A, Russo R, et al. An orally administered butyrate-releasing derivative reduces neutrophil recruitment and inflammation in dextran sulphate sodium-induced murine colitis. Br J Pharmacol. (2017) 174:1484-96. doi: 10.1111/bph.13637

72. Cassir N, Benamar S, La Scola B. Clostridium butyricum: from beneficial to a new emerging pathogen. Clin Microbiol Infect. (2016) 22:3745. doi: 10.1016/j.cmi.2015.10.014

73. Sun M, Wu W, Liu Z, Cong Y. Microbiota metabolite short chain fatty acids, GPCR, and inflammatory bowel diseases. J Gastroenterol. (2016) 52:1-8. doi: 10.1007/s00535-016-1242-9

74. Jia L, Shan K, Pan L, Feng N, Lv Z, Sun Y, et al. Clostridium butyricum CGMCC0313.1 protects against autoimmune diabetes by modulating intestinal immune homeostasis and inducing pancreatic regulatory $\mathrm{T}$ cells. Front Immunol. (2017) 8:1345. doi: 10.3389/fimmu.2017.01345

75. Howarth GS, Wang H. Role of endogenous microbiota, probiotics and their biological products in human health. Nutrients. (2013) 5:5881. doi: $10.3390 /$ nu5010058

76. Zhang J, Sun J, Chen X, Nie C, Zhao J, Guan W, et al. Combination of Clostridium butyricum and corn bran optimized intestinal microbial fermentation using a weaned pig model. Front Microbiol. (2018) 9:3091. doi: 10.3389/fmicb.2018.03091

77. Guo P, Zhang K, Ma X, He P. Clostridium species as probiotics: potentials and challenges. J Anim Sci Biotechnol. (2020) 11:24. doi: 10.1186/s40104-019-0402-1

78. Uryu H, Tsukahara T, Ishikawa H, Oi M, Otake S, Yamane I, et al Comparison of productivity and fecal microbiotas of sows in commercial farms. Microorganisms. (2020) 8:1469. doi: 10.3390/microorganisms8101469

79. Rivera-Chávez F, Zhang LF, Faber F, Lopez CA, Byndloss MX, Olsan EE, et al. Depletion of butyrate-producing clostridia from the gut microbiota drives an aerobic luminal expansion of Salmonella. Cell Host Microbe. (2016) 19:443-54. doi: 10.1016/j.chom.2016.03.004

80. Piva A, Morlacchini M, Casadei G, Gatta PP, Biagi G, Prandini A. Sodium butyrate improves growth performance of weaned piglets during the first period after weaning. Ital J Anim Sci. (2002) 1:3541. doi: 10.4081 /ijas.2002.35 
81. Hou Y, Wang L, Yi D, Ding B, Chen X, Wang Q, et al. Dietary supplementation with tributyrin alleviates intestinal injury in piglets challenged with intrarectal administration of acetic acid. Br J Nutr. (2014) 111:1748-58. doi: 10.1017/S0007114514000038

82. Hu $\mathrm{X}$, Lin $\mathrm{B}$, Luo $\mathrm{M}$, Zheng $\mathrm{X}$, Zhang $\mathrm{H}$. The isolation, identification, physiological property of pig-isolate Clostridium butyricum LY33 using lactic acid and its effects on intestinal function of weaned piglets. Ital J Anim Sci. (2019) 18:1:910-21. doi: 10.1080/1828051X.2019.1603089

83. Hamer HM, Jonkers D, Venema K, Vanhoutvin S, Troost FJ, Brummer RJ. Review article: the role of butyrate on colonic function. Aliment Pharmacol Ther. (2008) 27:104e19. doi: 10.1111/j.1365-2036.2007.03562.x

84. Yang CM, Cao GT, Ferket PR, Liu TT, Zhou L, Zhang L, et al. Effects of probiotic, Clostridium butyricum, on growth performance, immune function, and cecal microflora in broiler chickens. Poult Sci. (2012) 91:21219. doi: 10.3382/ps.2011-02131

85. Kelsic ED, Zhao J, Vetsigian K, Kishony R. Counteraction of antibiotic production and degradation stabilizes microbial communities. Nature. (2015) 521:516-9. doi: 10.1038/nature14485

86. Argüello H, Estellé J, Zaldívar-López S, Jiménez-Marín Á, Carvajal A, LópezBascón MA, et al. Early Salmonella Typhimurium infection in pigs disrupts microbiome composition and functionality principally at the ileum mucosa. Sci Rep. (2018) 8:7788. doi: 10.1038/s41598-018-26083-3

87. Richards JD, Gong J, de Lange CFM. The gastrointestinal microbiota and its role in monogastric nutrition and health with an emphasis on pigs: current understanding possible modulations, and new technologies for ecological studies. Can J Anim Sci. (2005) 85:421e35. doi: 10.4141/A05-049

88. Oh PL, Benson AK, Peterson DA, Patil PB, Moriyama EN, Roos S, et al. Diversification of the gut symbiont Lactobacillus reuteri as a result of hostdriven evolution. ISME J. (2010) 4:377-87. doi: 10.1038/ismej.2009.123

89. Hou C, Zeng X, Yang F, Liu H, Qiao S. Study and use of the probiotic Lactobacillus reuteri in pigs: a review. J Anim Sci Biotechnol. (2015) 6:14. doi: 10.1186/s40104-015-0014-3

90. Gresse R, Chaucheyras-Durand F, Fleury MA, Van de Wiele T, Forano E, Blanquet-Diot S. Gut microbiota dysbiosis in postweaning piglets: understanding the keys to health. Trends Microbiol. (2017) 25:85173. doi: 10.1016/j.tim.2017.05.004

91. Dou S, Gadonna-Widehem P, Rome V, Hamoudi D, Rhazi L, Lakhal $\mathrm{L}$, et al. Characterisation of early-life fecal microbiota in susceptible and healthy pigs to post-weaning diarrhoea. PLoS ONE. (2017) 12:e0169851. doi: 10.1371/journal.pone.0169851

92. Frese SA, Parker K, Calvert CC, Mills DA. Diet shapes the gut microbiome of pigs during nursing and weaning. Microbiome. (2015) 3:28. doi: 10.1186/s40168-015-0091-8

93. Yang Y, Galle S, Le MHA, Zijlstra RT, Gänzle MG. Feed fermentation with reuteran- and levan-producing Lactobacillus reuteri reduces colonization of weaning pigs by enterotoxigenic Escherichia coli. Appl Environ Microbiol. (2015) 81:5743-52. doi: 10.1128/AEM.01525-15

94. Fairbrother JM, Nadeau E, Gyles CL. Escherichia coli in postweaning diarrea in pigs: an update on bacterial types, pathogenesis, and prevention strategies. Anim Health Res Rev. (2005) 6:17-39. doi: 10.1079/AHR2005105

95. Katsuda K, Kohmoto M, Kawashima K, Tsunemitsu H. Frequency of enteropathogen detection in suckling and weaned pigs with diarrhea in Japan. J Vet Diag Invest. (2006) 18:350-4. doi: 10.1177/104063870601800405

96. Mori K, Ito T, Miyamoto H, Ozawa M, Wada S, Kumagai Y, et al. Oral administration of multispecies microbial supplements to sows influences the composition of gut microbiota and fecal organic acids in their post-weaned piglets. J Biosci Bioeng. (2011) 112:145-50. doi: 10.1016/j.jbiosc.2011.04.009

97. Wang W, Gänzle M. Toward rational selection criteria for selection of probiotics in pigs. Adv Appl Microbiol. (2019) 107:83-112. doi: 10.1016/bs.aambs.2019.03.003

98. Kreuzer S, Machnowska P, Aßmus J, Sieber M, Pieper R, Schmidt MF, et al. Feeding of the probiotic bacterium Enterococcus faecium NCIMB 10415 differentially affects shedding of enteric viruses in pigs. Vet Res. (2012) 43:58. doi: 10.1186/1297-9716-43-58

99. Bednorz C, Guenther S, Oelgeschläger K, Kinnemann B, Pieper R, Hartmann S, et al. Feeding the probiotic Enterococcus faecium strain NCIMB 10415 to piglets specifically reduces the number of Escherichia coli pathotypes that adhere to the gut mucosa. Appl Environ Microbiol. (2013) 79:7896904. doi: 10.1128/AEM.03138-13

100. Scharek-Tedin L, Kreuzer-Redmer S, Twardziok SO, Siepert B, Klopfleisch $\mathrm{R}$, Tedin $\mathrm{K}$, et al. Probiotic treatment decreases the number of CD14-expressing cells in porcine milk which correlates with several intestinal immune parameters in the piglets. Front Immunol. (2015) 6:108. doi: 10.3389/fimmu.2015.00108

101. Starke IC, Pieper R, Neumann K, Zentek J, Vahjen W. Individual responses of mother sows to a probiotic Enterococcus faecium strain lead to different microbiota composition in their offspring. Benef Microbes. (2013) 4:34556. doi: 10.3920/BM2013.0021

102. Liu H, Zhang J, Zhang S, Yang F, Thacker PA, Zhang G, et al. Oral administration of Lactobacillus fermentum I5007 favors intestinal development and alters the intestinal microbiota in formula-fed piglets. $J$ Agric Food Chem. (2014) 62:860-6. doi: 10.1021/jf403288r

103. Wang A, Yu H, Gao X, Li X, Qiao S. Influence of Lactobacillus fermentum I5007 on the intestinal and systemic immune responses of healthy and E. coli challenged piglets. Antonie Van Leeuwenhoek. (2009) 96:8998. doi: 10.1007/s10482-009-9339-2

104. Wang X, Yang F, Liu C, Zhou H, Wu G, Qiao S, et al. Dietary supplementation with the probiotic Lactobacillus fermentum 15007 and the antibiotic aureomycin differentially affects the small intestinal proteomes of weanling piglets. J Nutr. (2012) 142:7-13. doi: 10.3945/jn.111.147074

105. Wang AN, Cai CJ, Zeng XF, Zhang FR, Zhang GL, Thacker PA, et al. Dietary supplementation with Lactobacillus fermentum I5007 improves the anti-oxidative activity of weanling piglets challenged with diquat. $J$ Appl Microbiol. (2013) 114:1582-91. doi: 10.1111/jam.12188

106. Wang Z, Zeng X, Mo Y, Smith K, Guo Y, Lin J. Identification and characterization of a bile salt hydrolase from Lactobacillus salivarius for development of novel alternatives to antibiotic growth promoters. Appl Environ Microbiol. (2012) 78:8795-802. doi: 10.1128/AEM.02519-12

107. Yu H, Wang A, Li X, Qiao S. Effect of viable Lactobacillus fermentum on the growth performance, nutrient digestibility and immunity of weaned pigs. $J$ Anim Feed Sci. (2008) 17:61-9. doi: 10.22358/jafs/66470/2008

108. Sayan H, Assavacheep P, Angkanaporn K, Assavacheep A. Effect of Lactobacillus salivarius on growth performance, diarrhea incidence, fecal bacterial population and intestinal morphology of suckling pigs challenged with F4+ enterotoxigenic Escherichia coli. Asian Aust J Anim Sci. (2018) 31:1308-14. doi: 10.5713/ajas.17.0746

109. Sonia TA, Ji H, Hong-Seok M, Chul-Ju Y. Evaluation of Lactobacillus and Bacillus-based probiotics as alternatives to antibiotics in enteric microbial challenged weaned piglets. Afr J Microbiol Res. (2014) 8:96104. doi: 10.5897/AJMR2013.6355

110. Bohmer BM, Kramer W, Roth-Maier DA. Dietary probiotic supplementation and resulting effects on performance, health status, and microbial characteristics of primiparous sows. J Anim Physiol Anim Nutr. (2006) 90:309-15. doi: 10.1111/j.1439-0396.2005.00601.x

111. Taras D, Vahjen W, Macha M, Simon O. Performance, diarrhea incidence, and occurrence of Escherichia coli virulence genes during long-term administration of a probiotic Enterococcus faecium strain to sows and piglets. J Anim Sci. (2006) 84:608-17. doi: 10.2527/2006.843608x

112. Martin L, Pieper R, Kröger S, Goodarzi Boroojeni F, Vahjen W, Neumann K, et al. Influence of age and Enterococcus faecium NCIMB 10415 on development of small intestinal digestive physiology in piglets. Anim Feed Sci Technol. (2012) 175:65-75. doi: 10.1016/j.anifeedsci.2012. 04.002

113. Baker AA, Davis E, Spencer JD, Moser R, Rehberger T. The effect of a Bacillus-based direct-fed microbial supplemented to sows on the gastrointestinal microbiota of their neonatal piglets. J Anim Sci. (2013) 91:3390-9. doi: 10.2527/jas.2012-5821

114. Kritas SK, Marubashi T, Filioussis G, Petridou E, Christodoulopoulos G, Burriel AR, et al. Reproductive performance of sows was improved by administration of a sporing bacillary probiotic (Bacillus subtilis C-3102). J Anim Sci. (2015) 93:405-13. doi: 10.2527/jas.2014-7651

115. Starke IC, Zentek J, Vahjen W. Effects of the probiotic Enterococcus faecium NCIMB 10415 on selected lactic acid bacteria and enterobacteria in coculture. Benef Microbes. (2015) 6:345-52. doi: 10.3920/BM2014.0052 
116. Tan C, Zhai Z, Ni X, Wang H, Ji Y, Tang T, et al. Metabolomic profiles reveal potential factors that correlate with lactation performance in sow milk. Sci Rep. (2018) 8:10712. doi: 10.1038/s41598-018-28793-0

117. Gueimonde M, Flórez AB, de los Reyes-Gavilán CG, Margolles A. Intrinsic resistance in lactic acid bacteria and bifidobacteria: the role of multidrug resistance transporters. Int J Probiotics Prebiotics. (2009) 4:181-6.

118. Gueimonde M, Sánchez B, de Los Reyes-Gavilán CG, Margolles A. Antibiotic resistance in probiotic bacteria. Front Microbiol. (2013) 4:202. doi: $10.3389 /$ fmicb.2013.00202

119. Delcour J, Ferain T, Deghorain M, Palumbo E, Hols P. The biosynthesis and functionality of the cell-wall of lactic acid bacteria. Antonie Van Leeuwenhoek. (1999) 76:159-184. doi: 10.1023/A:1002089722581

120. Flórez AB, Ladero V, Alvarez-Martín P, Ammor MS, Alvarez MA, Mayo B. Acquired macrolide resistance in the human intestinal strain Lactobacillus rhamnosus $\mathrm{E} 41$ associated with a transition mutation in $23 \mathrm{~S}$ rRNA genes. Int J Antimicrob Agents. (2007) 30:341-4. doi: 10.1016/j.ijantimicag.2007.06.002

121. Græsbøll K, Larsen I, Clasen J, Birkegård AC, Nielsen JP, Christiansen $\mathrm{LE}$, et al. Effect of tetracycline treatment regimens on antibiotic resistance gene selection over time in nursery pigs. BMC Microbiol. (2019) 19:269. doi: 10.1186/s12866-019-1619-z

122. Schmidt GV, Mellerup A, Christiansen LE, Stahl M, Olsen JE, Angen O. Sampling and pooling methods for capturing herd level antibiotic resistance in swine feces using qPCR and CFU approaches. PLoS ONE. (2015) 10:e0131672. doi: 10.1371/journal.pone.0131672

123. Birkegard AC, Ersboll AK, Halasa T, Clasen J, Folkesson A, Vigre H, et al. Spatial patterns of antimicrobial resistance genes in a cross-sectional sample of pig farms with indoor non-organic production of finishers. Epidemiol Infect. (2017) 145:1418-30. doi: 10.1017/S0950268817000206

124. Aquilanti L, Garofalo C, Osimani A, Silvestri G, Vignaroli C, Clementi F. Isolation and molecular characterization of antibiotic-resistant lactic acid bacteria from poultry and swine meat products. J Food Prot. (2007) 70:55765. doi: 10.4315/0362-028X-70.3.557

125. Garofalo C, Vignaroli C, Zandri G, Aquilanti L, Bordoni D, Osimani A, et al. Direct detection of antibiotic resistance genes in specimens of chicken and pork meat. Int J Food Microbiol. (2007) 113:7583. doi: 10.1016/j.ijfoodmicro.2006.07.015

126. Vescovo M, Morelli L, Bottazzi V, Gasson, MJ. Conjugal transfer of broadhost-range plasmid pAMbetal into enteric species of lactic acid bacteria. Appl Environ Microbiol. (1983) 46:753-5. doi: 10.1128/AEM.46.3.753-755. 1983

127. Tannock GW, Luchansky JB, Miller L, Connell H, Thode-Andersen S, Mercer AA, et al. Molecular characterization of a plasmidborne (pGT633) erythromycin resistance determinant (ermGT) from Lactobacillus reuteri 100-63. Plasmid. (1994) 31:60-71. doi: 10.1006/plas. 1994.1007
128. Mater DD, Langella P, Corthier G, Flores MJ. A probiotic Lactobacillus strain can acquire vancomycin resistance during digestive transit in mice. $\mathrm{J} \mathrm{Mol}$ Microbiol Biotechnol. (2008) 14:123-7. doi: 10.1159/000106091

129. Simeoni D, Rizzotti L, Cocconcelli P, Gazzola S, Dellaglio F, Torriani S. Antibiotic resistance genes and identification of staphylococci collected from the production chain of swine meat commodities. Food Microbiol. (2008) 25:196-201. doi: 10.1016/j.fm.2007.09.004

130. Feld L, Schjorring S, Hammer K, Licht TR, Danielsen M, Krogfelt K, et al. Selective pressure affects transfer and establishment of a Lactobacillus plantarum resistance plasmid in the gastrointestinal environment. $J$ Antimicrob Chemother. (2008) 61:845-52. doi: 10.1093/jac/dkn033

131. Levy SB, FitzGerald GB, Macone AB. Changes in intestinal flora of farm personnel after introduction of a tetracycline-supplemented feed on a farm. N Engl J Med. (1976) 295:583-8. doi: 10.1056/NEJM197609092951103

132. Smith DL, Harris AD, Johnson J, Silbergeld EK, Morris JG. Animal antibiotic use has an early but important impact on the emergence of antibiotic resistance in human commensal bacteria. Proc Natl Acad Sci USA. (2002) 99:6434-9. doi: 10.1073/pnas.082188899

133. Silbergeld EK, Graham J, Price LB. Industrial food animal production, antimicrobial resistance, and human health. Annu Rev Public Health. (2008) 29:151-69. doi: 10.1146/annurev.publhealth.29.020907.090904

134. Starke IC, Pieper R, Neumann K, Zentek J, Vahjen W. The impact of high dietary zinc oxide on the development of the intestinal microbiota in weaned piglets. FEMS Microbiol Ecol. (2014) 87:41627. doi: 10.1111/1574-6941.12233

135. Vahjen W, Pietruszyńska D, Starke IC, Zentek J. High dietary zinc supplementation increases the occurrence of tetracycline and sulfonamide resistance genes in the intestine of weaned pigs. Gut Pathog. (2015) 7:23. doi: 10.1186/s13099-015-0071-3

136. Ciesinski L, Guenther S, Pieper R, Kalisch M, Bednorz C, Wieler LH. High dietary zinc feeding promotes persistence of multi-resistant E. coli in the swine gut. PLoS ONE. (2018) 13:e0191660. doi: 10.1371/journal.pone. 0191660

Conflict of Interest: The authors declare that the research was conducted in the absence of any commercial or financial relationships that could be construed as a potential conflict of interest.

Copyright (c) 2021 Sobrino, Alba, Arroyo, Pérez, Sariego, Delgado, Fernández, de María, Fumanal, Fumanal and Rodríguez. This is an open-access article distributed under the terms of the Creative Commons Attribution License (CC BY). The use, distribution or reproduction in other forums is permitted, provided the original author(s) and the copyright owner(s) are credited and that the original publication in this journal is cited, in accordance with accepted academic practice. No use, distribution or reproduction is permitted which does not comply with these terms. 